\title{
The Effect of Seed Priming and Accelerated Aging on Germination and Physiochemical Changes in Milk Thistle (Silybum marianum)
}

\author{
Ghasem PARMOON ${ }^{*}$, Ali EBADI', Soodabeh JAHANBAKHSH', Mahdi DAVARI² \\ ${ }^{1}$ University of Mohaghegh Ardabili, Faculty of Agriculture, Department of Agronomy, Daneshgah Street, Ardabil, Iran; \\ ghasem.parmoon@gmail.com (*correspondingauthor),ebadi@uma.ac.ir,soodabehjahanbakhsh@yahoo.com \\ ${ }^{2}$ University of Mohaghegh Ardabili, Faculty of Agriculture, Department of Plant Protection, Daneshgah Street, Ardabil, Iran; mdavari@uma.ac.ir
}

\begin{abstract}
Effects of seed priming and aging on some physiological characteristics of Milk thistle was studied in a factoral experiment based on Complete Randomized Design (CRD). Tratments were included hydro priming (using distilled water), halo priming $(0,1.5,3,4.5$ and $\left.6 \% \mathrm{KNO}_{3}\right)$ and accelerated aging $\left(0,2,4\right.$ and 6 days under $45^{\circ} \mathrm{C}$ and $95 \%$ humidity) in three replications. Determined parameters were germination charactristics including germination percentage, daily germination speed, mean time of germination, seed vigor index, hypocutile length and hypocutile dry weight. Activity of catalase, peroxidase and polyphenol oxidase were determined at 12 hours after imbibition and seedling stage. According to results of this experiment, germination percentage, seed vigor and seedling growth of seeds were increased under all priming treatments. Improving the catalase and peroxidase activity led to decrease the aging damages. Germination characteristics were improved under both priming treatments at the beginning of germination as well as seedling growth. Polyphenol oxidase activity was increased in the pre-treated seeds but decreased in seedling growth stage. Aging treatments led to reduce the germination percentage, daily germination speed, seed vigor and seedling growth while the germination time was increased. Accelerated aging caused to reduce the germination rate and seedling growth of milk thistle that is probably due to increasing the lipid peroxidation, free radical increment and decreasing the antioxidants activity. The greatest and lowest antioxidants activity, the germination percentage, germination speed and seed vigor were respectively observed under priming using $3 \% \mathrm{KNO}_{3}$ concentration and control seeds.
\end{abstract}

Keywords: accelerated aging, antioxidant activity, halo priming, milk thistle seeds

\section{Introduction}

Plant products, as parts of foods or botanical potions have been used with varying success to cure and prevent diseases throughout some years (Raskin et al., 2002). Traditional herbal medicines have long been a key component of healthcare systems in the developing world (Ma et al., 2005). Most medicinal plants are collected from the wild. Cultivation of these plants is needed to ensure their availability to industry, as well as those people associated with traditional systems of medicine. By bringing herbs into cultivation, traditional and biotechnological plantbreeding techniques can be applied at the genetic level to improve yield and uniformity, and to modify potency. Conventional plant-breeding methods can improve both agronomic and medicinal traits (Canter et al., 2005). Milk thistle (S. Marianum L. Gaertn.) is a troublesome weed as well as cultivated as a medicinal plant (Khan et al., 2009).

Milk thistle is native to the Mediterranean basin and is now widespread throughout the world. It is found on roadsides and waste ground, and in cereals crops. Seeds of milk thistle have been used for more than 2000 years to treat liver diseases. The hepatoprotective action of si- lymarin is mainly through its anti-free radical and anticarcinogenic roles, antioxidant, anti-lipid peroxidative, antifibrotic, antiinflammatory, immunomodulatory and liver regenerating activity and is subject to enterohepatic circulation (Kren and Walterova, 2005; Shaker et al., 2010). The valuable medicinal compounds of are found in the seeds of plant. The seeds contain the highest amount of silymarin (Engelberth et al., 2008; Sersen et al., 2006) and 25\% (w/w) oil (Wallace et al., 2005), but the whole plant is used medicinally. Also, Seeds of milk thistle contain small amounts of flavonoids (taxifolin) and approximately 20-35\% fatty acids and other polyphenolic compounds (Ramasamy and Agarwal, 2008). Silymarin is a strong antioxidant that has been proven to promote liver cell regeneration, reduce blood cholesterol and help to prevent cancer (Vaknin et al., 2008). Silymarin is a lipophilic which extracted from the seeds of milk thistle and is composed of three isomer flavonolignans, silybin, silydianin and silychristin. Each flower head produces about 190 seeds, with an average of 6350 seeds per plant (Dodd, 1989). In the soil, seed can remain viable for up to nine years (Sindel, 1991). The seeds show little or no dormancy. Storage of seeds for a long period cause their deterioration 
and reduce their survival. Accelerated aging of seeds is different between various plant species and inside one seed clone but it induced by several days of exposure to high temperature and high humidity (Priestley, 1986). Accelerated aging also resulted in increased lipid peroxidation, decreased levels of anti-oxidants and reduced activity of several enzymes involved in scavenging of free radicals and peroxides (Bailly et al., 1998; Chiu et al., 1995; Hsu and Sung, 1997). Thus, reduced anti-oxidative activities, along with other mechanisms, may contribute to the increased susceptibility to deterioration of primed seeds. During aging, free radicals cause damage to cells and cell death finally. Some studies have shown the role of free radicals in aging plants and animals as well as seeds of various plants (Bailly et al., 1996; Kranner et al., 2006). If ROS and hydrogen peroxidase rise a lot more than critical level, can be caused severe damage to the cell membranes due to increased production of $\mathrm{OH}$ (Bienert et al., 2006). Oxidative stress is an interaction of the imbalance between ROS production and defense antioxidant against ROS. This result in an oxidative stress is because of Enhancement of combined big molecules with oxygen. In order to inhibition of oxidative damage to tissues, the cells equipped with various enzymes and non-enzymatically for detoxify. The protectant enzymes including Superoxide dismutase that remove oxidizing $\mathrm{O}_{2}^{-}$ions through decomposition into hydrogen Proxidase hydrogen and could be broken and change to oxygen and $\mathrm{H}_{2} \mathrm{O}$ by catalase. Other antioxidants comprise proxidase, glutathione and ascorbate (Kibinza et al., 2011).

Priming is an important way for enhancing of seed germination. Priming is the process of partial and monitoring discharge of seeds to begin the biochemical processes and metabolism of sugars and hydrolysis inhibitors during the first and second stages of germination before radicle emergence. Priming enhanced germination and reduced germination rate. The priming reduces the effects of aging by reducing Malondialdehyde (MDA) and free radicals production and maintenance antioxidant activities. The radical and seedling growth increase during priming (Basra et al., 2003).The environmental factors effect on seed maturation and agronomic quality of Milk thistle as well as some treatment impact on the enhancement ability of the seeds. The aim of recent study was to evaluate the Milk thistle seed tolerance to wearing and introduce the ways to reduce the effects of aging on.

\section{Materials and methods}

\section{Seed materials}

In order to perform accelerated aging treatments, seeds were incubated inside the sealed boxes with $90 \%$ to $95 \%$ relative humidity and afterwards placed at $45^{\circ} \mathrm{C}$ for 2,4 and 6 days. 150 seeds were placed inside two filters paper (for hydration inhibition) and prepared osmolites for seed priming were added to them, subsequently incubated at $25^{\circ} \mathrm{C}$ in darkness for 12 hours. Treatments included hydro priming and halo priming with $\mathrm{KNO}_{3}$ at concentrations of $1.5 \%, 3 \%, 4.5 \%$ and $6 \%$.

\section{Germination test}

To test the germination of Milk thistle seeds, 25 seeds disinfected with $1 \%$ sodium hypochlorite for 5 minutes then placed in petri dishes with two layers of filter paper. Germination rate evaluated each dayfor 12 days, and seedling size (Hypocotyl) measured. The seedling dry weight (Hypocotyl) was obtained after putting in the oven $75^{\circ} \mathrm{C}$ for $48 \mathrm{~h}$

\section{Mean time to germination ( $M T G$ )}

Average seed germination rate was calculated as one index of the germination rate according to Ellis and Roberts (1981), Wherease $n$ shows the number of germinated seeds in d days and $(\Sigma(\mathrm{nd}))$ as total germinated seeds:

$$
\mathrm{MTG}=(\Sigma(\mathrm{nd})) /(\Sigma \mathrm{n})
$$

\section{Daily germination Speed (DGS)}

Daily germination rate was estimated by of using the Maguire (1962), Daily average germination was calculated according to Hunter et al. (1984) in that FGP is the germination percentage, and $\mathrm{D}$ show the days up to achieve maximum germination rate:

$$
\begin{aligned}
& \mathrm{MDG}=\mathrm{FGP} / \mathrm{D} \\
& \mathrm{DGS}=1 / \mathrm{MDG}
\end{aligned}
$$

\section{Seedling vigor index}

First and second seed vigor index was calculated using the following equation (Abdul-Baki and Anderson, 1973):

$$
\begin{aligned}
& \mathrm{SV}_{1}=\text { seedling dry weight }(\mathrm{g}) \times \text { germination }(\%) \\
& \mathrm{SV}_{2}=\text { seedling dry length }(\mathrm{cm}) \times \text { germination }(\%)
\end{aligned}
$$

\section{Determination of enzyme activities}

The enzyme activity was measured twice, 12 hours after the seed imbibition and in the Hypocotyl stage. To measure the enzyme activity of the seeds, 25 seeds were grounded and after that $0.2 \mathrm{~g}$ of the obtained powder were used for measuring and for seedlings, $0.2 \mathrm{~g}$ of fresh tissue was used. In order to extract protein, $0.2 \mathrm{~g}$ of fresh tissue plant was pulverized in a mortar using liquid nitrogen and then one $\mathrm{ml}$ of buffer Tris- $\mathrm{HCl}(0.05 \mathrm{M}, \mathrm{pH}=7.5)$ was added. Obtained mixture centrifuged for $20 \mathrm{~min}$ at $13,000 \mathrm{rpm}$, at $4^{\circ} \mathrm{C}$ and the supernatant was used for enzyme activity measurements (Sudhakar et al., 2001).

Catalase activity was assayed according to kar and Mishra (1976). The 60ul protein extract was added to Tris buffer $(50 \mathrm{mM}, \mathrm{pH}=7) \mathrm{H}_{2} \mathrm{O}_{2} 5 \mathrm{mM}$ in the ice bath, then the absorbance curve was considered at a wavelength of $240 \mathrm{~nm}$. Enzyme activity was obtained for OD/ mg protein fresh tissue. Peroxidase activity measured as described by Kar and Mishra (1976): $50 \mu$ l protein extract was added to $2.5 \mathrm{ml}$ extraction buffer containing $100 \mu \mathrm{M}$ Tris buf- 
206

fer $100 \mathrm{mM}$ and hydrogen peroxide five $\mathrm{mM}$ and $10 \mathrm{mM}$ Pirogalol in the ice bath and absorbance changes was read at a wavelength of $425 \mathrm{~nm}$ graph. Furthermore, Polyphenol oxidase enzyme activity was measured by Kar and Mishra (1976) method. $100 \mu \mathrm{l}$ protein extract was solved in $1.5 \mathrm{ml}$ Tris $0.2 \mathrm{M}$ and $0.3 \mathrm{ml}$ Pirogalol $0.02 \mathrm{M}$ and the resulting composition was placed in the bain marie bath at $25^{\circ} \mathrm{C}$ for five minimums and then the absorbance rate at $420 \mathrm{~nm}$ was recorded. The evaluation of protein carried out by Bradford (1976) method. $0.2 \mathrm{~g}$ of plant tissue was squashed with $0.6 \mathrm{ml}$ extraction buffer and centrifuged in $11,500 \mathrm{rpm}$ for $20 \mathrm{~min}$ at $4^{\circ} \mathrm{C}$. The supernatant transferred to in the new tubes and centrifuged for 20 minutes at $4000 \mathrm{rpm}$ and the supernatant was obtained. To measure protein amount, $10 \mu \mathrm{l}$ obtained to extract was added to $5 \mu \mathrm{l}$ Bradford solution and $290 \mu \mathrm{l}$ extraction buffer and the absorbance rate was read at $595 \mathrm{~nm}$.

\section{Statistics}

An experimental design was arranged in factorial based on a completely randomized design (CRD) with three replications. Means were compared using the LSD method with $\mathrm{P}$ value $=0.05$. Most of the measured traits were significant at $p=0.05$.

\section{Results and discussion}

Crop seeds live on the environment for several days or years after harvest to start a new growth stage (planting seeds) which causes influence the agronomical quality of seeds. Seed vigor is the main characteristic of crop seed quality. Among the factors affecting seed vigor the maturity stage at harvesting and the seed aging are important (McDonald, 1999), which is influenced by environmental conditions that they placed in. Untreated seeds (control) showed $54 \%$ germination percentage which might be due to seeds dormancy. Priming enhances germination of Milk thistle seeds up to $81 \%$. Maximum enhancement belonged to $\mathrm{KNO}_{3} 3 \%$ concentrations (from $54 \%$ to $81 \%$ ) while the minimum exhibited at concentrations of $1.5 \%$ from $54 \%$ to $60 \%$. (Fig. 1., A). The aging reduced the germination from $54 \%$ to $60 \%$ (Fig. 1., B).

The seed germination rate was equal to 0.53 days in the controls and it was reduced using priming treatments. $\mathrm{KNO}_{3} 3 \%$ and $1.5 \%$ concentrations exhibited the highest germination rate equal to 0.34 days (Tab. 1). Aging of seeds increased the daily germination rate (from 0.53 to 0.63 ). Among all treatments, $\mathrm{KNO}_{3} 3 \%$ improved germination during the aging so in the highest aging, daily germination rate reduced from 0.69 to 0.57 days whereas at $\mathrm{KNO} 4.5 \%$ (Tab. 1) it was very lowe (decreased from 0.69 to 0.67 days). Priming increased hypocotyl length and dry weight. Hypocotyl length and dry weight increased during priming with $\mathrm{KNO}_{3} 141 \%$ and $90 \%$, respectively. The concentration of $\mathrm{KNO}_{3}$ at $6 \%$ exhibited minimal impact on the Hypocotyl length and dry weight (Tab. 1).

Hypocotyl length reduced during aging (decreased from 2.06 to 1.76 and $1.75 \mathrm{~cm}$ at various levels of aging) as well as hypocotyl dry weight (reduced from 1.73 to 1.53 $\mathrm{mg}$ ). At high levels of aging, $\mathrm{KNO}_{3} 3 \%$ exhibited the most positive effect ( length increased from 1.75 to $2.96 \mathrm{~cm}$ ) on the hypocotyl length among other treatments and $\mathrm{KNO}_{3}$ at $1.5 \%$ concentration increased it from 1.53 to $1.80 \mathrm{mg}$ and exhibited the highest influence on the dry weight of hypocotyl (Tab. 1).

Seed vigor is another which affecting seed germination and seedling growth, increase during priming. Among the treatments, the most effective on the first (increased from 0.09 to 0.27 ) and second (increased from 99.9 to 400.1 ) vigor belonged to $3 \% \mathrm{KNO}_{3}$ and the lowest was $6 \% \mathrm{KNO}_{3}$. Seed vigor is the first traits would be affected during aging. Both vigor indexs were changed from 0.09 to 0.05 and 99.9 to 71.1 in first and second vigor index, respectively. Priming reduced the aging effect. Among the treatments, $\mathrm{KNO}_{3} 3 \%$ exhibited the highest effect on the aging (increase of first vigor from 0.05 to 0.08 and the scond vigor index from 71.1 to 138.2 at 6 days aging) (Tab. 1). Mean time of seed germination reduced by seed
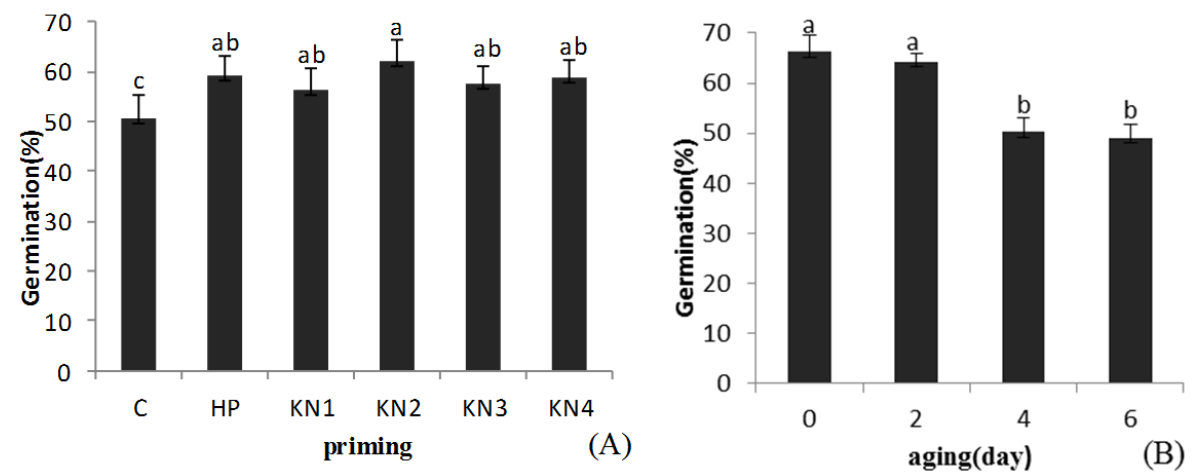

Fig. 1. Effect of seed priming and accelerated aging treatment on germination of milk thistle seeds. A (C: control, HP: Hydro Priming, KN1: Priming with $\mathrm{KNO}_{3} 1.5 \%$, KN2: Priming with $\mathrm{KNO}_{3} 3 \%, \mathrm{KN}_{3}$ : Priming with $\mathrm{KNO}_{3} 4.5 \%$, KN4: Priming with $\mathrm{KNO}_{3} 6 \%$ ) and $\mathrm{B}$ (non aging, 2 day aging, 4 day aging and 6 day aging) 
Tab. 1. Amounts of DGS, Hypocotyl length, Hypocotyl dry weight, SVI ${ }_{1}$ and SVI 2 subjected to different treatments

\begin{tabular}{|c|c|c|c|c|c|c|}
\hline Seed treatment & $\begin{array}{l}\text { Aging } \\
\text { (day) }\end{array}$ & DGS & $\operatorname{HYL}(\mathrm{cm})$ & HYDW (mg) & $\mathrm{SVI}_{1}$ & $\mathrm{SVI}_{2}$ \\
\hline \multirow{4}{*}{ Control } & 0 & $0.53 \pm 0.07$ & $2.06 \pm 0.24$ & $1.73 \pm 0.07$ & $0.09 \pm 0.010$ & $99.9 \pm 15.4$ \\
\hline & 2 & $0.43 \pm 0.01$ & $2.16 \pm 0.44$ & $2.13 \pm 0.18$ & $0.13 \pm 0.010$ & $138.2 \pm 28.5$ \\
\hline & 4 & $0.63 \pm 0.07$ & $1.76 \pm 0.26$ & $1.53 \pm 0.07$ & $0.06 \pm 0.008$ & $76.2 \pm 02.7$ \\
\hline & 6 & $0.69 \pm 0.03$ & $1.75 \pm 0.05$ & $1.53 \pm 0.24$ & $0.05 \pm 0.005$ & $71.1 \pm 14.1$ \\
\hline \multirow{4}{*}{ Hydro priming } & 0 & $0.36 \pm 0.01$ & $3.04 \pm 0.20$ & $2.43 \pm 0.10$ & $0.18 \pm 0.007$ & $235.1 \pm 12.2$ \\
\hline & 2 & $0.45 \pm 0.02$ & $3.72 \pm 0.27$ & $3.07 \pm 0.07$ & $0.18 \pm 0.004$ & $227.3 \pm 10.8$ \\
\hline & 4 & $0.53 \pm 0.05$ & $2.10 \pm 0.16$ & $2.00 \pm 0.12$ & $0.10 \pm 0.010$ & $114.6 \pm 12.5$ \\
\hline & 6 & $0.62 \pm 0.04$ & $2.51 \pm 0.14$ & $1.67 \pm 0.74$ & $0.08 \pm 0.030$ & $113.2 \pm 17.6$ \\
\hline \multirow{4}{*}{$\mathrm{KNO}_{3}(1.5 \%)$} & 0 & $0.54 \pm 0.10$ & $3.62 \pm 0.52$ & $2.87 \pm 0.13$ & $0.16 \pm 0.040$ & $215.5 \pm 79.2$ \\
\hline & 2 & $0.42 \pm 0.02$ & $4.03 \pm 0.46$ & $2.47 \pm 0.18$ & $0.16 \pm 0.010$ & $270.6 \pm 39.3$ \\
\hline & 4 & $0.47 \pm 0.03$ & $3.09 \pm 0.89$ & $2.00 \pm 0.12$ & $0.10 \pm 0.010$ & $178.5 \pm 38.4$ \\
\hline & 6 & $0.56 \pm 0.04$ & $2.82 \pm 0.08$ & $1.80 \pm 0.12$ & $0.08 \pm 0.010$ & $121.1 \pm 25.7$ \\
\hline \multirow{4}{*}{$\mathrm{KNO}_{3}(3 \%)$} & 0 & $0.34 \pm 0.01$ & $4.97 \pm 0.75$ & $3.33 \pm 0.13$ & $0.27 \pm 0.007$ & $400.1 \pm 46.3$ \\
\hline & 2 & $0.48 \pm 0.03$ & $2.64 \pm 0.07$ & $1.87 \pm 0.07$ & $0.10 \pm 0.008$ & $154.7 \pm 9.35$ \\
\hline & 4 & $0.50 \pm 0.07$ & $2.22 \pm 0.40$ & $1.80 \pm 0.12$ & $0.09 \pm 0.010$ & $151.9 \pm 28.5$ \\
\hline & 6 & $0.57 \pm 0.07$ & $2.96 \pm 0.16$ & $1.40 \pm 0.12$ & $0.08 \pm 0.010$ & $138.2 \pm 26.0$ \\
\hline \multirow{4}{*}{$\mathrm{KNO}_{3}(4.5 \%)$} & 0 & $0.44 \pm 0.02$ & $4.10 \pm 0.67$ & $2.40 \pm 0.23$ & $0.15 \pm 0.010$ & $261.6 \pm 42.6$ \\
\hline & 2 & $0.45 \pm 0.04$ & $2.87 \pm 0.50$ & $1.73 \pm 0.07$ & $0.10 \pm 0.010$ & $186.6 \pm 53.6$ \\
\hline & 4 & $0.47 \pm 0.05$ & $2.32 \pm 0.35$ & $1.67 \pm 0.07$ & $0.10 \pm 0.010$ & $143.8 \pm 18.3$ \\
\hline & 6 & $0.67 \pm 0.07$ & $2.34 \pm 0.13$ & $1.47 \pm 0.07$ & $0.06 \pm 0.005$ & $96.9 \pm 9.40$ \\
\hline \multirow{4}{*}{$\mathrm{KNO}_{3}(6 \%)$} & 0 & $0.47 \pm 0.06$ & $2.44 \pm 0.23$ & $1.60 \pm 0.12$ & $0.09 \pm 0.010$ & $153.3 \pm 34.6$ \\
\hline & 2 & $0.38 \pm 0.01$ & $3.05 \pm 0.45$ & $1.73 \pm 0.18$ & $0.12 \pm 0.008$ & $217.8 \pm 26.9$ \\
\hline & 4 & $0.54 \pm 0.05$ & $2.65 \pm 0.41$ & $1.53 \pm 0.07$ & $0.07 \pm 0.010$ & $143.2 \pm 29.8$ \\
\hline & 6 & $0.59 \pm 0.08$ & $2.90 \pm 0.42$ & $1.37 \pm 0.03$ & $0.07 \pm 0.004$ & $132.8 \pm 38.0$ \\
\hline $\mathrm{LSD}_{005}$ & & 0.14 & 1.16 & 0.05 & 0.04 & 91.94 \\
\hline
\end{tabular}

DGS; Daily germination Speed, HYL; Hypocotyl length, HYDW; Dry weight Hypocotyl, SVIl first Seedling vigor index and SVI $_{2 ;}$ secondary Seedling vigor index

priming. Potassium nitrate $1.5 \%$ had the maximum effect on the mean time of germination (it decreased 37\%) and $\mathrm{KNO}_{3} 6 \%$ showed the minimum effect (down from 3.29 to 2.39 days). During aging, the mean time of germination was increased (increasing from 2.09 to 2.73) (Tab. 2).

Lin and Sung (2001) and Hsu et al. (2003) showed effectivness of seed priming on the germination in bitter gourd at low temperature and aging conditions. Our results showed that the enhancement of seed germination, and improve establishment candidate factors (including mean germination time, germination rate and seed vigor) are due to the priming. Lipid peroxidation reduction and the antioxidant activity enhancement are the factors that priming affects on germination. Priming can increase the seed survival and improve the stored seeds in the unfavorable conditions. Hsu et al. (2003) reported that priming and pre-soaking of bitter gourd seeds enhance the seed germination percentage and reduce its mean time. Also, the aging reduces seed germination percentage and seed vigor and increase the mean time of germination. The priming and soaking in warm water increased Catalase, Ascorbate peroxidase and superoxide dismutase activity and soluble protein content and reduce malondialdehyde levels and total peroxidase and their enhancement over the aging. They believed that priming and soaking the seeds in warm water for a few hours is suitabl for long surviving period.
In our study we have found that the rate of the antioxidant activity (Catalase and Peroxidase) reduce both before germination and during hypocotyl growth stage resulting the reduction of seed vigor, whereas the priming with $\mathrm{KNO}_{3}$ $3 \%$ created their highest activity and reduced the effects of aging. Increased activity of this enzyme in the germination initial increases seed germination percentage and speed in which the seedling growth rate improved, too. This finding can be help seedlings to better posture in the field and increased yield. Seed viability declines during aging according to Sung and Jeng (1994) results. Kibinza et al. (2011) indicated the reduction of germination percentage during aging while priming with amino acid improves the aged seed. They believe that the decline during aging, resulting in decreased Catalase activities and its improvement during the priming causes seed to be recovered (Pyfrom $e t$ al., 1957; Racusen, 1958).

Catalase enzyme activity at germination stage and during the seedling growth was increased by seed priming. Potassium nitrate $3 \%$ and $6 \%$ showed the highest and lowest activity compared to controls (Tab. 2). Over hypocotyl growth, $\mathrm{KNO}_{3} 1.5 \%$ exhibited the greatest (an increase from 1.25 to $2.81 \mathrm{OD} / \mathrm{mg}^{-1}$ protein) whereas $\mathrm{KNO}_{3} 4.5 \%$ showed the lowest enzyme activity (reduction from 1.25 to $1.07 \mathrm{OD} / \mathrm{mg}^{-1}$ protein) (Tab. 3). Aging reduced the catalase activity from 8.13 to $5.49 \mathrm{OD} / \mathrm{mg}^{-1}$ protein be- 
208

fore germination and from 1.25 to $0.79 \mathrm{OD} / \mathrm{mg}^{-1}$ protein during the hypocotyl growth (Tab. 2, 3). Results showed that $\mathrm{KNO}_{3} 3 \%$ was the compensation better than other treatments (increased from 5.14 to $9.26 \mathrm{OD} / \mathrm{mg}^{-1}$ protein before germination and from 0.79 to 1.71 and $1.29 \mathrm{OD} /$ $\mathrm{mg}^{-1}$ protein in the Hypocotyl stage in 4 and 6 days aging respectively) (Tab. 2,3).

Peroxidase activity was increased in the primed seeds before germination and during hypocotyl growth. Before germination, peroxidase activity had the maximum activity at $\mathrm{KNO}_{3} 3 \%$ (it was increased from 5.94 to $11.45 \mathrm{OD} /$ $\mathrm{mg}^{-1}$ protein) and the lowest activity $\left(7.61 \mathrm{OD} / \mathrm{mg}^{-1}\right.$ protein) obtained by $\mathrm{KNO}_{3} 6 \%$.(Tab. 2). Milk thistle Seed aging led to reduction in peroxidase activity at hypocotyl growth stage, and this effect increases in high levels of aging (reduction of enzyme activity from 3.72 to $1.80 \mathrm{OD} / \mathrm{mg}^{-1}$ protein). Priming treatments reduced aging effect. Among treatments, $\mathrm{KNO}_{3} 3 \%$ and hydro-priming exhibited the maximum $\left(18.6 \mathrm{OD} / \mathrm{mg}^{-1}\right.$ protein $)$ and minimum enzyme activity (4.11 OD $/ \mathrm{mg}^{-1}$ protein) respectively (Tab. 3 ).

Catalase and Peroxidase activity was reduced during aging. Reductionof the replication in the genes related to their reduce RNA oxidase activity during aging due to decreases of $\mathrm{H}_{2} \mathrm{O}_{2}$ leading to increase their activity. Because of the increase in $\mathrm{H}_{2} \mathrm{O}_{2}$ and free radicals in the stressed cell cytoplasm during oxidative stress, the proton production in the mitochondria increase and leading to inactivation of photosynthetic as well as the non-equilibrium between ROS and antioxidants and also in the reduction of the protein cohesion protein may cause increased protein sensitivity to the protease enzymes, leading to a reduction of seed viability. The priming improves and repairs the gene expression and increases their activity during germination (Berlett and Stadtman, 1997; Kibinza et al., 2006). The antioxidants, especially catalase prevent oxidative ROS activity and then augmentation of enzyme activity increase protolytic discounting because of cadmium (Shimizu and Kobayashi, 1984; Romero-Pubertas et al., 2002). The aging changes the place of some amino acids and iron-sulfur in structures of some antioxidants resulting ROS activity enhancement. Catalase accumulates in the cytosol during priming simultaneously with hydrogen peroxide localization. Seed protein and nucleic acid synthesis increases and allows different metabolic processes of DNA replication or the synthesis of ethylene (Bray et al., 1995; Fu et al., 1988).

Polyphenol oxidase activity was also influenced by seed priming and aging, so that the activity was increased by seed priming before germination and was reduced over hypocotyl growth. On the other hand, seed aging enhanced polyphenol oxidase activity both before germination and seedling growth. The highest enzyme activity $(6.25 \mathrm{OD} /$ $\mathrm{mg}^{-1}$ protein) was observed at $3 \% \mathrm{KNO}_{3}$ and the lowest (4 $\mathrm{OD} / \mathrm{mg}^{-1}$ protein) in the control seeds. Also, the enzyme activity increased over aging from 3.80 to $6.24 \mathrm{OD} / \mathrm{mg}^{-1}$ protein (Tab. 2). Enzyme activity at hypocotyl growth stage had the highest rate in the control treatment $(2.54$ $\mathrm{OD} / \mathrm{mg}^{-1}$ protein) and the lowest rate in $3 \% \mathrm{KNO}_{3}(1.18$ $\mathrm{OD} / \mathrm{mg}^{-1}$ protein). Enzyme activity rate increased over the aging so that its activity in control seeds was $2.54 \mathrm{OD} /$ $\mathrm{mg}^{-1}$ protein while enhanced to $3.60 \mathrm{OD} / \mathrm{mg}^{-1}$ protein during the aging (Tab. 3).

Priming could not improve the germination at high levels of aging because irreversible damage repair may not be (Butler et al., 2009). During the programmed cell death (PCD), Catalase rate and sensitivity reduce and indicate that the aging causes PCD and subsequent the reduction of seed's viability. Hydro-praming and priming with ascorbic acid improved germination compared to control. Catalase and peroxidase enzyme activity decreased with increasing of aging severity and Hydropraming with ascorbic acid maintained a high activity of this enzyme

Tab. 2. Amounts of MTG, CAT, POX and PPO of milk thistle seeds subjected to various treatments after 12 hours imbibition

\begin{tabular}{|c|c|c|c|c|}
\hline Seed treatment & MTG & $\begin{array}{c}\text { CAT } \\
\left(\mathrm{OD} / \mathrm{mg}^{-1} \text { protein }\right)\end{array}$ & $\begin{array}{c}\text { POX } \\
\left(\mathrm{OD} / \mathrm{mg}^{-1} \text { protein }\right)\end{array}$ & $\begin{array}{c}\text { PPO } \\
(\mathrm{OD} / \mathrm{mg}-1 \text { protein })\end{array}$ \\
\hline \multicolumn{5}{|c|}{ Priming } \\
\hline Control & $3.29 \pm 0.15$ & $5.14 \pm 0.50$ & $05.94 \pm 0.95$ & $04.00 \pm 0.75$ \\
\hline Hydro priming & $2.16 \pm 0.14$ & $7.67 \pm 0.43$ & $09.07 \pm 1.04$ & $04.76 \pm 0.63$ \\
\hline $\mathrm{KNO}_{3}(1.5 \%)$ & $2.01 \pm 0.12$ & $8.50 \pm 0.92$ & $10.74 \pm 1.60$ & $04.97 \pm 0.63$ \\
\hline $\mathrm{KNO}_{3}(3 \%)$ & $2.26 \pm 0.11$ & $9.26 \pm 1.55$ & $11.45 \pm 1.77$ & $06.25 \pm 0.71$ \\
\hline $\mathrm{KNO}_{3}(4.5 \%)$ & $2.08 \pm 0.10$ & $7.35 \pm 0.64$ & $09.09 \pm 1.12$ & $04.99 \pm 0.52$ \\
\hline $\mathrm{KNO}_{3}(6 \%)$ & $2.39 \pm 0.16$ & $6.87 \pm 0.53$ & $07.61 \pm 0.87$ & $05.40 \pm 0.45$ \\
\hline $\mathrm{LSD}_{0.05}$ & 0.29 & 2.52 & 2.54 & 1.47 \\
\hline \multicolumn{5}{|c|}{ Aging (day) } \\
\hline 0 & $2.09 \pm 0.13$ & $8.13 \pm 0.47$ & $10.30 \pm 1.44$ & $03.65 \pm 0.52$ \\
\hline 2 & $2.12 \pm 0.12$ & $8.88 \pm 0.43$ & $11.63 \pm 1.12$ & $04.93 \pm 0.50$ \\
\hline 4 & $2.51 \pm 0.13$ & $7.36 \pm 0.96$ & $08.12 \pm 0.44$ & $05.43 \pm 0.48$ \\
\hline 6 & $2.73 \pm 0.16$ & $5.49 \pm 0.76$ & $05.88 \pm 0.56$ & $06.23 \pm 0.42$ \\
\hline $\mathrm{LSD}_{0.05}$ & 0.23 & 2.06 & 2.89 & 1.52 \\
\hline
\end{tabular}

MTG; Mean time to germination, CAT; Catalase, POX; Peroxidase and PPO; poly phenol oxidase 
Tab. 3. Amounts of CAT, POA and PPO of milk thistle Hypocotyl subjected to various treatments

\begin{tabular}{|c|c|c|c|c|}
\hline Priming & $\begin{array}{l}\text { Aging } \\
\text { (day) }\end{array}$ & $\begin{array}{c}\text { CAT } \\
\left(\mathrm{OD} / \mathrm{mg}^{-1} \text { protein }\right)\end{array}$ & $\begin{array}{c}\text { POX } \\
\left(\mathrm{OD} / \mathrm{mg}^{-1} \text { protein }\right)\end{array}$ & $\begin{array}{c}\mathrm{PPO} \\
\left(\mathrm{OD} / \mathrm{mg}^{-1} \text { protein }\right)\end{array}$ \\
\hline \multirow{4}{*}{ Control } & 0 & $1.25 \pm 0.04$ & $3.72 \pm 0.17$ & $2.54 \pm 0.22$ \\
\hline & 2 & $1.20 \pm 0.09$ & $3.40 \pm 0.13$ & $2.94 \pm 0.22$ \\
\hline & 4 & $1.16 \pm 0.01$ & $2.67 \pm 0.22$ & $3.28 \pm 0.29$ \\
\hline & 6 & $0.79 \pm 0.01$ & $1.80 \pm 0.02$ & $3.60 \pm 0.01$ \\
\hline \multirow{4}{*}{ Hydro priming } & 0 & $1.46 \pm 0.21$ & $4.11 \pm 0.19$ & $2.18 \pm 0.21$ \\
\hline & 2 & $1.18 \pm 0.21$ & $3.52 \pm 0.05$ & $2.31 \pm 0.36$ \\
\hline & 4 & $1.08 \pm 0.05$ & $3.10 \pm 0.05$ & $2.56 \pm 0.29$ \\
\hline & 6 & $0.86 \pm 0.07$ & $1.98 \pm 0.04$ & $2.92 \pm 0.22$ \\
\hline \multirow{4}{*}{$\mathrm{KNO}_{3}(1.5 \%)$} & 0 & $2.81 \pm 0.18$ & $5.86 \pm 0.61$ & $2.44 \pm 0.11$ \\
\hline & 2 & $1.74 \pm 0.01$ & $4.22 \pm 0.75$ & $2.63 \pm 0.13$ \\
\hline & 4 & $1.71 \pm 0.11$ & $3.65 \pm 0.05$ & $3.01 \pm 0.23$ \\
\hline & 6 & $1.29 \pm 0.25$ & $3.30 \pm 0.30$ & $3.32 \pm 0.45$ \\
\hline \multirow{4}{*}{$\mathrm{KNO}_{3}(3 \%)$} & 0 & $2.39 \pm 0.08$ & $6.18 \pm 0.35$ & $1.18 \pm 0.01$ \\
\hline & 2 & $1.63 \pm 0.18$ & $4.36 \pm 0.23$ & $1.24 \pm 0.04$ \\
\hline & 4 & $1.36 \pm 0.04$ & $3.91 \pm 0.27$ & $1.40 \pm 0.03$ \\
\hline & 6 & $1.08 \pm 0.01$ & $3.72 \pm 0.12$ & $1.64 \pm 0.04$ \\
\hline \multirow{4}{*}{$\mathrm{KNO}_{3}(4.5 \%)$} & 0 & $1.07 \pm 0.03$ & $4.66 \pm 0.49$ & $1.28 \pm 0.02$ \\
\hline & 2 & $1.79 \pm 0.04$ & $4.09 \pm 0.15$ & $1.34 \pm 0.02$ \\
\hline & 4 & $1.31 \pm 0.14$ & $3.32 \pm 0.19$ & $1.51 \pm 0.14$ \\
\hline & 6 & $0.89 \pm 0.04$ & $3.07 \pm 0.02$ & $2.06 \pm 0.01$ \\
\hline \multirow{4}{*}{$\mathrm{KNO}_{3}(6 \%)$} & 0 & $1.99 \pm 0.12$ & $4.36 \pm 0.48$ & $1.62 \pm 0.02$ \\
\hline & 2 & $1.56 \pm 0.08$ & $3.87 \pm 0.16$ & $1.90 \pm 0.06$ \\
\hline & 4 & $1.12 \pm 0.06$ & $3.13 \pm 0.06$ & $2.04 \pm 0.07$ \\
\hline & 6 & $1.09 \pm 0.06$ & $2.73 \pm 0.07$ & $2.21 \pm 0.04$ \\
\hline $\mathrm{LSD}_{005}$ & & 0.32 & 0.81 & 0.42 \\
\hline
\end{tabular}

compared to control (Goel et al., 2003). Priming and aging are effective on the seed germination rate and pursuant to the seed's vigor. High seed vigor increase the potential of further growth of seedling, and it cause additional dry matter accumulation as well as dry matter. Our results also showed the enhancement of up to germination speed, seed vigor and increase's seedling longitudinal growth and dry weight over priming and reduce them during aging. Seed germination rate and vigor are important indicators of seed quality and influenced seed viability. Rao $e t$ al. (2006) showed that accelerated aging to reduces the onion seed's vigor. They believe that the decline of seed vigor affected by reducing in antioxidant enzyme activity and increased levels of ROS and malondialdehyde rate during germination and seedling growth. The magnitude of ROS affected by the amount of unsaturated fatty acids and less influenced in the seeds with higher levels of saturated fatty. (Kalpana and Madhava Rao, 1994). Since 50\% to $60 \%$ milk thistle seed oil are formed from unsaturated fatty acid oleic acid, so it is likely that the seeds produce freer radicals lead to their aging. Perhaps Silymarin found in the milk thistle seed acts as a protective role due to its antioxidant activity against lipid peroxidation and reduces seeds aging (Ghosh et al. 2010). The polyphenol oxidase enzyme was significant compared with other enzymes; however, there was no significant relationship to the ag- ing or priming. Polyphenol oxidase is found in higher plants and its main task catalysis of Quinones of phenol in the presence of oxygen molecules. The enzyme activity also depends upon the plant genotype and growth conditions. Polyphenol oxidase role for the plant, including its effect on Adventitious root forming, root growth organization (Yilmaz et al., 2003) and its role in cell division and primary differentiation and development (Huystee and Cairns, 1982). $\mathrm{KNO}_{3} 3 \%$ was the best treatment among of priming methods used in the present study about the most measured characters represents an appropriate level of milk thistle seed priming. It seems that adjustment in elements exchanged of the cell membrane of the seeds in milk thistle is the most important factor that could influence the seed aging improvement.

\section{Conclusions}

Potassium nitrate has a positive effect on Antioxidant enzymes activity and is probably highly effective to remove damages of aging.

\section{Acknowledgment}

We would like to thank for Dr. Zahri, Mr. Khabiri also Ms. Ali Rezai for his support and encouragement. 
210

\section{References}

Abdul-Baki AA, Anderson JD (1973). Vigor determination in soybean by multiple criteria. Crop Science 13:630-633.

Able AJ, Guest DI, Sutherland MW (2000). Hydrogen peroxide yields during the incompatible interaction of tobacco suspension cells inoculated with Phytophthora nicotianae. Plant Physiol 124:899-910.

Bailly C, Benamar A, Corbineau F, Côme D (1996). Changes in malondialdehyde content and in superoxide dismutase, catalase and glutathione reductase activities in sunflower seeds as related to deterioration during accelerated aging. Physiol Plant 97:104-110.

Basra SMA, Ahmad N, Khan MM, Iqbal N, Cheema MA (2003). Assessmentof cotton seed deterioration during accelerate. Seed Sci Technol 31:531-540.

Berlett BS, Stadtman ER (1997). Protein oxidation in aging, disease, and oxidative stress. J Biol Chem 272:20313-20316.

Bienert GP, Schjoerringa JK, Jahn TP (2006). Membrane transport of hydrogen peroxide. Biomembranes1758 994-1003.

Bradford MM (1976). A rapid and sensitive for the quantitation of microgram quantities of protein utilizing the principle of protein-dye binding. Analytical Biochemis 72:248-254.

Bray CM (1995). Biochemical processes during the osmopriming of seeds, 767-789 p. In: Kigel Y, Galili G (Eds.). Seed Development and Germination, Marcel Dekker, New York.

Butler LH, Hay FR, Ellis RH, Smith RD, Murray TB (2009). Priming and re-drying improve the survival of mature seeds of Digitalis purpurea during storage. Ann Bot 103:12611270.

Canter PH, Thomas H, Ernst E (2005). Bringing medicinal plants into cultivation. opportunities and challenges for biotechnology. Trends Biotechnol 23:180-185.

Ellis RH, Roberts EH (1981). The quantification of aging and survival in orthodox seeds. Seed Science and Technology 9:377-409.

Fu JR, Lu SH, Chen RZ, Zhang BZ, Liu ZS, Cai DY (1988). Osmoconditioning of peanut (Arachis hypogaea L.) seed with PEG to improve vigor and some biochemical activities. Seed Sci Tech 16:197-212.

Ghosh A, Ghosh T, Jain S (2010). Silymarin - a review on the pharmacodynamicsand bioavailability enhancement approaches. J Pharm Sci Technol 2:348-355.

Goel A, Goel AK, Sheoran IS (2003). Changes in oxidative stress enzymes during artificial ageing in cotton(Gossypium hirsutum L.) seeds. J Plant Physiol 160:1093-1100.

Hsu CC, Chen CL, Chen JJ, Sung JM (2003). Accelerated aging-enhanced lipid peroxidation in bitter gourd seeds and effects of priming and hot water soaking treatments. Sci Hortic 98:201-212.

Hunter EA, Glasbey CA, Naylor REL (1984). The analysis of data from germination tests. J Agric Sci, Cambridge 102:207-213.
Huystee RB, Cairns WL (1982). Progrenoand prospects in the use of peroxidase to study cell development. Phytochemistry 21:1843-1847.

Kalpana R, Madhava Rao KV (1994). Absence of the role of lipid peroxidation during accelerated ageing of seeds of pigeon pea (Cajanus cajan L.) Seed Sci Technol 22:253-260.

Kar M, Mishra D (1976). Catalase, peroxidase and polyphenol oxidase activity during rice leaf senescence. Plant Physiol 57:315-319.

Khan MZ, Blackshaw RE, Marwat KB (2009). Biology of milk thistle (Silybum marianum) and the management options for growers in north-western Pakistan. Weed Biol Manage 9:99-105.

Kibinza S, Bazin J, Bailly Ch, Farrant JM, Corbineau F, Maarouf-Bouteau HE (2011). Catalase is a key enzyme in seed recovery from ageing during priming. Plant Science 181:309315 .

Kibinza S, Vinel D, Côme D, Bailly C, Corbineau F (2006). Sunflower seed deterioration as related to moisture content during ageing, energy metabolism and active oxygen species scavenging. Physiol Plant 128:496-506.

Kranner I, Birtic S, Anderson KM, Prichard HW (2006). Glutathione half-cell reduction potential:a universal stress marker and modulator of programmed cell death. Free Radic Biol Med 40:2155-2165.

Kren V, Walterova D (2005). Silibin and silymarin. New effects and applications. Biomed. Pap 149:29-41.

Lin JM, Sung JM (2001). Pre-sowing treatments for improving emergence of bitter gourd seedlings under optimal and suboptimal temperatures. Seed Sci Technol 29:39-50.

Ma JKC, Chikwamba R, Sparrow P, Fischer R, Mahoney R, Twyman RM (2005). Plant-derived pharmaceuticals the road forward. Trends Plant Sci 10: 580-585.

Maguire JD (1962). Speed of germination, aid in selection and evaluation for seedling emergence and vigor. Crop Science 2:176-177.

McDonald MB (1999). Seed deterioration: physiology, repair and assessment. Seed Sci Technol 27:177-237.

Priestley DA (1986). Seed Aging. Implications of Seed Storage and Persistence in the Soil, Cornell University Press, Ithaca, NY.

Pyfrom HT, Appelman DW, Heim G (1957). Catalase and chlorophyll depression by 3-amino-1,2,4-triazol. Plant Physiol 32:674.

Racusen D (1958). The metabolism and translocation of 3-amino-1,2,4-triazol in plants. Arch Biochem Biophys 74:106.

Ramasamy K, Agarwal R (2008). Multitargeted therapy of cancer by silymarin. Cancer Lett 269:352-362.

Rao RGS, Singh PM (2006). Mathura Rai Storability of onion seeds and effects of packaging and storage conditions on viability and vigor. Sci Hortic 110:1-6.

Raskin I, Ribnicky DM, Komarnytsky S, Ilic N, Poulev A, Borisjuk N, Brinker A, Moreno DA, Ripoll C, Yakoby N, 
O’Neal JMO, Cornwell T, Pastor I, Fridlender B (2002). Plants and human health in the twenty-first century. Trends Plant Sci 20:522-531.

Romero-Puertas MC, Palma JM, Gómez M, Del Río LA, Sandalio LM (2002). Cadmium causes the oxidative modification of proteins in pea plants. Plant Cell Environ 25:677-686.

Shaker E, Mahmoud H, Mnaa S (2010). Silymarin, the antioxidant component and Silybum marianum extracts prevent liver damage. Food Chem Toxicol 48:803-806.

Shimizu N, Kobayashi K (1984). The reaction of superoxide radical with catalase. Mechanism of the inhibition of catalase by superoxide radical. J Biol Chem 259:4414-4418.

Sindel BM (1991). A review of the ecology and control of thistles in Australia. Weed Res 31:189-201.
Sudhakar C, Lakshmi A, Giridara KS (2001). changes in the antioxidant enzyme efficacy in two high yielding genotypes of mulberry (Mours alba L.) under $\mathrm{NaCl}$ salinity. Plant Sci 167:613-619.

Sung JM, Jeng TL (1994). Lipid peroxidation and peroxidescavenging enzymes associated with accelerated aging of peanut seed. Physiol Plant 91:51-55.

Yilmaz H, Taskin T, Otludil B (2003). Polyphenol oxidase activity during rooting in cuttings of grape (Vitis vinifera L.) varieties. Turk J Bot 27:495-498. 